\title{
Overview on the Use of Natural Gas in Spark Ignition Engines
}

\author{
Robert Marian POPA*, Rodica NICULESCU, Adrian CLENCI, Victor IORGA- \\ SIMĂN \\ University of Pitesti, Pitesti, Romania
}

*Corresponding author e-mail: poparobertmarian@yahoo.com

Article history

Received 15.11 .2020

Accepted 20.01.2021

DOI https://doi.org/10.26825/bup.ar.2021.004

\begin{abstract}
As air pollution and global warming become a priority in sustainable mobility, the evolution of vehicles is facing many regulations that are becoming increasingly stringent in terms of reducing greenhouse gas (GHG) emissions, forcing the automotive industry to search for solutions to make their products more environmentally friendly.

In this environmental and legislative context, considerable attention has been given to natural gas (NG) in spark ignition (SI) engines. Many studies have been conducted to assess the impacts of NG use on engine operation.

This overview paper discusses some aspects of recent studies on Natural Gas (NG) production, its physico-chemical properties, and also, on the influence of the use of compressed natural gas $(\mathrm{CNG})$ in SI engines: combustion characteristics, performance, and emissions.
\end{abstract}

Keywords: compressed natural gas, spark ignition engine, emissions

\section{Introduction}

Due to global warming through greenhouse gases, reducing $\mathrm{CO}_{2}$ emissions put much stress on the vehicle developers which should adopt different solutions in order to achieve the goal. In Europe, $\mathrm{CO}_{2}$ emissions from passenger car (PC) engines are regulated by EC Directive No 443/2009 [1], which also stipulates that starting with 2012, all manufacturers whose average emission of $\mathrm{CO} 2$ exceed the values permitted in already mentioned regulation, shall pay a fee for each calendar year for the emission excess. According to this regulation, for PC with the inertia class of $1380 \mathrm{~kg}$, from 2021, the limit value will be $95 \mathrm{~g} \mathrm{CO}_{2} / \mathrm{km}$ which corresponds to a fuel consumption of approximately $3.81 / 100 \mathrm{~km} \mathrm{[2].} \mathrm{The}$ automotive industry invests in vehicle with zero emissions (ZEV), ultra-low emission vehicle (ULEV), plug-in hybrid electric vehicle (PHEV) or battery electric vehicle (BEV), but, until they are reaching a more affordable cost for customer and until the efficiency of well-to-wheel will increase, there are other solutions, such as alternative fuel which will help to reduce the emissions and consequently greenhouse gases.

Out of the currently available alternative fuels, the methane gas is considered to be one of the best substitute for fossil fuels because, on the one hand, it's compatible with conventional spark or compression ignition engine and, on the other hand, it's eco-friendly due to its clean nature of combustion [3], [4]. Indeed, the favorable ratio of hydrogen to carbon in methane (1:4) means up to $30 \%$ lower $\mathrm{CO}_{2}$ emissions compared to gasoline [5]. In fact, as stated in [6], [7], methane combustion produces the lowest $\mathrm{CO}_{2}$ emissions of fossil fuels. Another positive aspect of methane is its wide 
availability, as pointed out by the CIA World Factbook [8] in its comprehensive country comparison from NG production.

In conclusion, methane seems to be a good alternative for spark-ignition engines.

\section{Literature review}

\subsection{Natural Gas production}

Natural gas can be extracted from nature or can be manufactured from plants or waste.Raw natural gas can be found in 3 types of wells: oil, gas and condensate. The gas extracted from oil wells is named associated gas, the gas extracted from gas wells and condensate wells is termed non associated gas. This gas is mixed with water vapour, $\mathrm{CO} 2$, Helium, Nitrogen which should be separated before being transported through pipelines to customer, becoming dry natural gas, which is, in fact only methane part [9], [10].

Bio-natural gas is obtained through waste processing (another problem humanity is facing). It can be created by anaerobic digestion of manure, waste water, plants and even waste food [11], [12].

As mentioned in [13], to obtain about $1 \mathrm{kWh}$ of electrical energy and $1.25 \mathrm{kWh}$ of thermal energy, the following amounts of raw materials constituting a basis for energy production from renewable sources are needed: $5-7 \mathrm{~kg}$ of biomass wastes, $5-15 \mathrm{~kg}$ of municipal solid wastes, $8-12 \mathrm{~kg}$ of manure and organic wastes and $4-7 \mathrm{~m}^{3}$ of municipal wastes.

\subsection{Physico-Chemical Properties of NG}

Natural Gas, is a mixture of various gases and its composition differ according to geographic location and period of the year of the extraction. The main components of NG are methane ( 90\%), ethane ( 4.6\%), propane ( 1\%) and others. A list of the most commonly seen components in NG is provided in Table 1.

Table 1. Composition of CNG

\begin{tabular}{|c|c|c|c|c|c|c|c|c|}
\hline $\begin{array}{c}\text { NG composition } \\
\text { Component }\end{array}$ & Symbol & \multicolumn{7}{|c|}{ Volumetric } \\
\hline Reference number & - & {$[14]$} & {$[15]$} & {$[16]$} & {$[17]$} & {$[18]$} & {$[19]$} & average \\
\hline Methane & $\mathrm{CH} 4$ & 89.10 & 85.79 & 94.42 & 88.98 & 88.10 & 95.30 & 90.28 \\
\hline Ethane & $\mathrm{C} 2 \mathrm{H} 6$ & 4.40 & 7.86 & 2.29 & 6.81 & 4.20 & 2.16 & 4.62 \\
\hline Propane & $\mathrm{C} 3 \mathrm{H} 8$ & 1.10 & 1.61 & 0.03 & 1.12 & 1.36 & 0.19 & 0.90 \\
\hline Butane & $\mathrm{C} 4 \mathrm{H} 10$ & 0.30 & 0.53 & 0.25 & 0.11 & 0.58 & 0.04 & 0.30 \\
\hline Pentane & $\mathrm{C} 5 \mathrm{H} 12$ & 0.10 & 0.12 & 0.00 & 0.02 & 0.15 & 0.01 & 0.07 \\
\hline Hexane & $\mathrm{C} 6 \mathrm{H} 14$ & 0.00 & 0.00 & 0.00 & 0.00 & 0.03 & 0.00 & 0.01 \\
\hline Nitrogen & $\mathrm{N} 2$ & 5.00 & 2.96 & 0.44 & 2.50 & 5.20 & 1.86 & 2.99 \\
\hline Carbon dioxide & $\mathrm{CO} 2$ & 0.00 & 1.04 & 0.57 & 0.43 & 0.30 & 0.44 & 0.46 \\
\hline Oxygen & $\mathrm{O} 2$ & 0.00 & 0.00 & 0.00 & 0.03 & 0.00 & 0.00 & 0.01 \\
\hline Helium & $\mathrm{He}$ & 0.00 & 0.09 & 0.00 & 0.00 & 0.00 & 0.00 & 0.02 \\
\hline Others & - & 0.00 & 0.00 & 2.00 & 0.00 & 0.08 & 0.00 & 0.35 \\
\hline Total & & 100 & 100 & 100 & 100 & 100 & 100 & 100 \\
\hline
\end{tabular}

So, the main component of natural gas is methane. Methane is a colourless and odourless gas. It's lighter than air with a relative density at boiling point of $0.424 \mathrm{~kg} / \mathrm{dm}^{3}$. The melting point of methane is $182.5^{\circ} \mathrm{C}$ and the boiling point is $-162^{\circ} \mathrm{C}$. It is an extremely flammable gas, its mixture with air between 5 to $15 \%$ volume becomes explosive [20][21]. Autoignition temperature is $537^{\circ} \mathrm{C}$. It should be 
manipulated with precaution because liquid state of methane on contact with skin can cause frostbites. There are also denied open flames, sparks and smoking near methane area because of its explosive tendency [22]. Chemical formula of methane is $\mathrm{CH}_{4}$ [20]. It has a molecular mass of $16 \mathrm{~g} / \mathrm{mol}$ and a tetrahedral form.
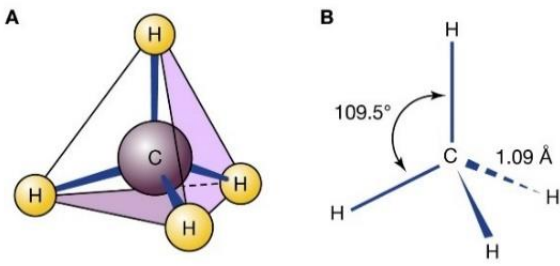

Figure 1. Methane molecular representation [20]

Making a comparison between most used vehicle fuels it can be observed that methane is as good as gasoline and diesel. In terms of $\mathrm{A} / \mathrm{F}$ ratio, stoichiometric density, flame propagation speed, adiabatic flame temperature and lower heating value (LHV) the compressed natural gas (CNG), liquefied petroleum gas (LGP), gasoline and diesel are pretty the same. CNG makes itself remarkable by its octane number, autoignition temperature and smaller number of carbon atoms (see table 2). These three main characteristics helps in knocking resistance and in obtaining low $\mathrm{CO} 2$ emissions when used in internal combustion engines. In present the optimal spark advance is determined using research octane number RON 105 fuel as reference. Using CNG which has a high-octane number, means that we can increase the compress ratio to higher values and together with optimal spark advance (because knocking is avoided) efficiency increases and the fuel consumption decreases.

Methane burning reaction in stoichiometric conditions gives $\mathrm{CO}_{2}$ and water vapour. The flame is pale, slightly luminous and very hot. In engine, because of low number of carbon atoms, it gives lower $\mathrm{CO}_{2}$ emissions, comparing with a molecule of gasoline (around eight carbon atoms)

$$
\begin{gathered}
\mathrm{CH}_{4}+\mathrm{O}_{2} \rightarrow \mathrm{CO}_{2}+2 \mathrm{H}_{2} \mathrm{O} \\
\mathrm{C}_{8} \mathrm{H}_{18}+12.5 \mathrm{O}_{2} \rightarrow 8 \mathrm{CO}_{2}+9 \mathrm{H}_{2} \mathrm{O}
\end{gathered}
$$

So, can be easily observed that gasoline produces eight times more $\mathrm{CO}_{2}$ than methane, reported to only one molecule of each fuel. Actually, the higher the number of carbon atom is, the higher the $\mathrm{CO}_{2}$ emissions will be.

\begin{tabular}{|c|c|c|c|c|c|c|c|c|c|c|c|c|c|c|c|c|c|c|c|c|}
\hline & & & & Gascire & & & & & & Ciesel & & & & & CNG & & & & Hydrogen & LPG \\
\hline 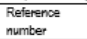 & [23] & [अ] & [24] & {$[14]$} & [16] & [25] & Average & [23] & [अ] & [24] & Average & [23] & [अ] & [24] & [14] & [16] & [25] & Average & [24] & [25] \\
\hline $\begin{array}{l}\text { Chenrical } \\
\text { formula }\end{array}$ & $\begin{array}{l}\text { C4 to } \\
\text { C12 }\end{array}$ & - & $\mathrm{C}^{2} \mathrm{H} 1.87 \mathrm{n}$ & - & . & $\begin{array}{l}\text { C4 to } \\
\text { C10 }\end{array}$ & . & $\begin{array}{l}\text { C8 to } \\
\text { C25 }\end{array}$ & . & $\mathrm{C}_{n+1,2 n}$ & - & $\mathrm{CH} 4$ & - & $\mathrm{CH} 4$ & - & - & $\mathrm{CH}_{4}$ & & $\mathrm{H}_{2}$ & $\begin{array}{l}\mathrm{C}_{3} \text { to } \\
\mathrm{C4}\end{array}$ \\
\hline $\begin{array}{l}\text { Molar macss } \\
\text { [kgimol] }\end{array}$ & $\cdot$ & 109 & . & 106.2 & 110 & - & 108.4 & - & 204 & . & 204 & - & 17.3 & - & 17.74 & 16.04 & - & 17.03 & . & - \\
\hline AF rabio & - & $\begin{array}{l}14.7 \\
\end{array}$ & 14.71 & 14.19 & 14.6 & 14.8 & 14.60 & - & 14.6 & 14.49 & 14.55 & - & 17.2 & 17.24 & 16.5 & 16.79 & 17.2 & 16.99 & 34.48 & 15.5 \\
\hline Fiarabio & - & 0.0680 & 0.0680 & 0.0705 & 0.0685 & 0.0676 & 0.0685 & - & 0.0685 & 0.0690 & 0.0687 & - & 0.0581 & 0.0520 & \begin{tabular}{|l}
0.0606 \\
\end{tabular} & \begin{tabular}{|l}
0.0596 \\
\end{tabular} & \begin{tabular}{|l}
0.0581 \\
\end{tabular} & 0.0539 & 0.0290 & 0.0645 \\
\hline $\begin{array}{l}\text { Density } \\
\text { @15["C } \\
\text { kggm3] }\end{array}$ & . & - & 750 & 749 & - & 730 & 743 & - & . & $827-840$ & 833.5 & - & . & 0.725 & . & . & 140 & 70.3625 & 0.09 & - \\
\hline $\begin{array}{l}\text { Strichiomethic } \\
\text { density [kgm } 3]\end{array}$ & $\cdot$ & 1.42 & - & - & 1.38 & - & 1.4 & - & 1.46 & - & 1.46 & - & 1.25 & - & - & 1.24 & - & 1.245 & - & - \\
\hline $\begin{array}{l}\text { Cetane } \\
\text { number }\end{array}$ & & & - & - & - & - & - & 45.55 & $45-55$ & 52 & 52 & - & - & - & - & - & - & - & & \\
\hline $\begin{array}{l}\text { Ooctane } \\
\text { number }\end{array}$ & 84.93 & $85-95$ & 95 & 95.8 & $80-90$ & 95 & 95.27 & - & - & - & & 120 & $\begin{array}{l}120- \\
130\end{array}$ & 120 & - & 120 & 120 & 120 & $>120$ & 105 \\
\hline $\begin{array}{l}\text { Auto ignition } \\
\text { temp [ }[\mathrm{C} C]\end{array}$ & 500 & 258 & 280 & - & $\begin{array}{l}482-1 \\
550\end{array}$ & 220 & 314.5 & 250 & 316 & 250 & 272 & 565 & 540 & 650 & - & 645 & 540 & 588 & 585 & - \\
\hline & 43.5 & 43.5 & 44 & 42.23 & 43.6 & 43.5 & 43.39 & 42.6 & 42.7 & 42.5 & 426 & 48.5 & 47.5 & 45 & 45.71 & 47.37 & 47.7 & 46.96 & 120 & 46.1 \\
\hline $\begin{array}{l}\text { LHV.Vof } \\
\text { mixture } \\
\text { (stochionethic) } \\
\text { [N/kgl] }\end{array}$ & . & 2.85 & - & - & 283 & - & 2.84 & - & 275 & . & 2.75 & 40.0 & 262 & - & . & 272 & . & 2.67 & 120 & 40.1 \\
\hline 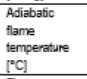 & 2025 & 2150 & - & . & . & - & 2088 & - & 2054 & - & 2054 & 1950 & 1890 & . & . & . & - & 1920 & - & - \\
\hline $\begin{array}{l}\text { Flame } \\
\text { propagation } \\
\text { speed [m/s] }\end{array}$ & . & 0.5 & . & - & . & - & 0.5 & - & . & - & - & - & 0.41 & - & . & . & - & 0.41 & - & - \\
\hline $\begin{array}{l}\text { Combustion } \\
\text { eneryy } \\
{[\text { [Mlm3] }}\end{array}$ & . & 42.7 & . & . & . & . & 427 & . & 36 & . & 36 & - & 24.6 & . & . & . & . & 24.6 & . & . \\
\hline
\end{tabular}

Table 2. Physico-chemical properties of fuels 


\section{Use of NG in SIE}

\subsection{Why compressed natural gas?}

The main advantage of natural gas already discussed in $\$ 2.2$ is its high-octane number which allows a high compression ratio which offers a high efficiency. This can be easily demonstrated using the thermodynamic efficiency formula of Otto cycle [23]:

where:

$$
\eta=1-\frac{1}{\varepsilon^{\gamma-1}}
$$

- $\gamma=\frac{c_{p}}{c_{v}}$ is the ratio between specific heat at constant pressure and specific heat at constant volume,

- $\varepsilon=\frac{V_{1}}{V_{2}}$ is the compression ratio of the engine.

It is observable that the thermodynamic efficiency of an Otto engine depends only by compression ratio because the adiabatic exponent is always super unitary and the higher the compression ratio, the higher the efficiency is.

Another very important feature of natural gas (if associating it with methane) especially in the current context which aims carbon neutrality is a favourable $\mathrm{C} / \mathrm{H}$ ratio (1:4), which results in a significant reduction of tailpipe $\mathrm{CO} 2$ emission as discussed in $\S 3.4 .2$.

Equally, it is important to mention the time for tank refilling. Methane, in its natural state (1.013 bar, 15 $\left.{ }^{\circ} \mathrm{C}\right)$ has a very low energy density $(0.0378 \mathrm{MJ} / \mathrm{L})$ compared with gasoline $(34,2 \mathrm{MJ} / \mathrm{L})$ and diesel fuel $(38.6 \mathrm{MJ} / \mathrm{L})$. To gain some energy, natural gas is compressed to around 250 bar and reaches an energy density of $9 \mathrm{MJ} / \mathrm{L}$ compared with natural state [24]-[26]. It is still not comparable with gasoline and diesel fuel, but it is a big step in gaining energy density. Thanks to fast filling process comparable with gasoline and diesel fuel, the low range of the vehicle would not be a problem if the coverage of the refilling stations is favourable.

\subsubsection{Short presentation of the particularities of a CNG fuel system}

In order to be able to use natural gas to power internal combustion engines, they need a few upgrades. Natural gas fuel system needs some specific parts for best results in running. Starting from tank filling point to the point where the gas goes in the cylinder, is needed [27], [28]:

1. Fuel filler is the place where the gas station is connected for refill;

2. Natural gas tanks which keep the high-pressure gas;

3. Regulator which reduces the high-pressure gas from tank to a lower value accepted by the engine system;

4. Natural gas fuel filter to keep unwanted particles which contaminates the gas;

5. Fuel line to transport the natural gas from tank to injectors. These are usually pipes under vehicle;

6. Specific sensors;

There are three types of specific sensors, as follows: a) sensor for tank pressure measures the pressure right before first reduction step; this signal is used by the ECU to calculate and actuate the natural gas gauge in the dashboard. b) sensor for gas fuel rail which measures the gas pressure in it; c) thermal safety sensor which allows the gas to be ejected in a controlled manner is case of fire; this sensor has a fluid which expands after a certain time and opens the gate to leave the gas out of tank.

7. Specific actuators. There are four types of specific actuators, as follows:

a) valve for tank shut-off (one for each tank) they turn on the gas when the ignition is switched on and gas mode is selected, putting the high-pressure side over pressure;

b) two stages high pressure regulator which reduces the high pressure from the tank ( 200bar) to a lower value around $9 \mathrm{bar}$; this reduction of pressure results in a rapid drop of pressure which can freeze the gas pressure regulator; for this reason, the regulator is connected to engine coolant to heat it up during functionality, keeping it at engine operating temperature; 
c) high pressure valve for gas mode lets the gas from tank to enter the regulator; it closes automatically in case of signal crash;

d) injectors - have the same construction and the same functionality as gasoline injectors

8. Electronic control unit (ECU) for controlling the system.

\subsubsection{Storage of $\mathrm{CH} 4$ and safety conditions of the pressurized cylinder}

Natural gas vehicles (NGV) receive NG from high pressure reservoirs. Because of its very low energy density at atmospheric pressure and room temperature, natural gas must be compressed and stored on the vehicle at high pressure - typically, $20 \mathrm{MPa}$ [29].

One can find four major types of natural gas cylinders for NGV accepted by NGV safety standards:

1. All metal cylinder (Fig. 2. a)

The seamless steel cylinder was the most widely used cylinder for natural gas storage of NGV since 1940. In 1970 Italy introduced a lightweight and a high-strength cylinder which was a big step forward in NGV industry, adopted all over the world. This is also the cheapest gas cylinder [30].

2. Hoop Wrapped Composite cylinder (Fig. 2. b)

These types of cylinders have a metal liner and a composite reinforcement on the straight side only. This type of container is a compromise between the low cost of all metal cylinder and the lighter cylinder from type 3 and 4 [30].

3. Fully Wrapped Composite with Metal Liner (Fig. 2. c)

This type of cylinder uses a seamless metal liner over wound on all surfaces by a composite reinforcement which provides between 75 to $90 \%$ of the strength of the tank. They are used also in portable applications such as breathing apparatus, medical oxygen storage, aircraft slide inflation [30].

4. Fully Wrapped Composite with Non-Metallic Liner (Fig. 2. d)

These containers have a plastic liner and a full overwrap of carbon fibre or mixed fibre construction. The main disadvantage of these tanks is that they provide no structural strength to the product and, also, they are not gas tight but, the rate of permeation is acceptable for use with CNG [30].

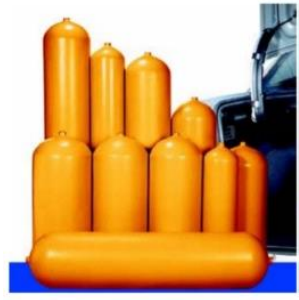

a)

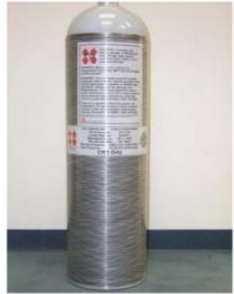

b)

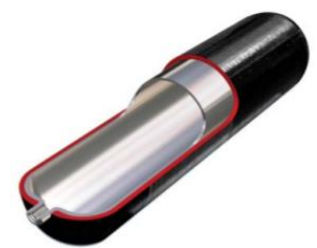

c)

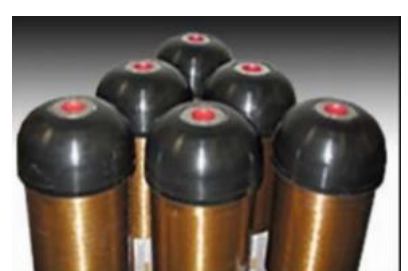

d)

Figure 2. a) Fully Wrapped Composite with Metal Liners; b) All metal cylinders; c) Hoop Wrapped Composite Cylinders; d) Fully Wrapped Composite with Non-Metallic Liners

In table 3. are indicated some prices for each type of cylinder and its mass in kilograms for each litre of tank capacity [30]

Table 3. CNG cylinder types cost and weight

\begin{tabular}{|c|c|c|}
\hline Cylinder type & Cost $[\$ / \mathbf{L}]$ & Weight $[\mathrm{kg} / \mathbf{L}]$ \\
\hline Steel type 1 & 6 to 10 & 0.9 to 1.2 \\
\hline Aluminium type 1 & 8 to 10 & 0.9 to 1.0 \\
\hline Metal, hoop wrapped & 10 to 15 & 0.8 to 0.6 \\
\hline Fully wound composite, aluminium liner & 20 to 25 & 0.3 to 0.4 \\
\hline Fully wound composite, plastic liner & 20 to 25 & 0.3 to 0.4 \\
\hline
\end{tabular}

CNG cylinders standards has a very complete series of safety criteria related to performance of the tank which covers burst pressure, life cycle, resistance to damage and effects of the extreme environment conditions. Because it's a safety piece, it has to pass some mandatory tests as mentioned in ISO 11439 . 


\subsubsection{Infrastructure in Europe}

It is well known that accessibility to fuel stations is very important. Just as petrol and diesel stations are widely available for all car ranges, so should be those for refuelling with CNG, and even more so, given the low energy density of CNG.

In Europe, the number of CNG stations are 3932 and 363 of LNG, according to Natural \& bio Gas Vehicle Association (NGVA) Europe (figure 3) [31]. According to [32], in Europe are 43140 LPG stations which means that NG stations are $90 \%$ fewer as number compared with LPG gas stations, but keeps increasing. Most developed infrastructure for NGV is in West Europe and Italy. In Romania there are 3 CNG gas stations and none of LNG. [31]

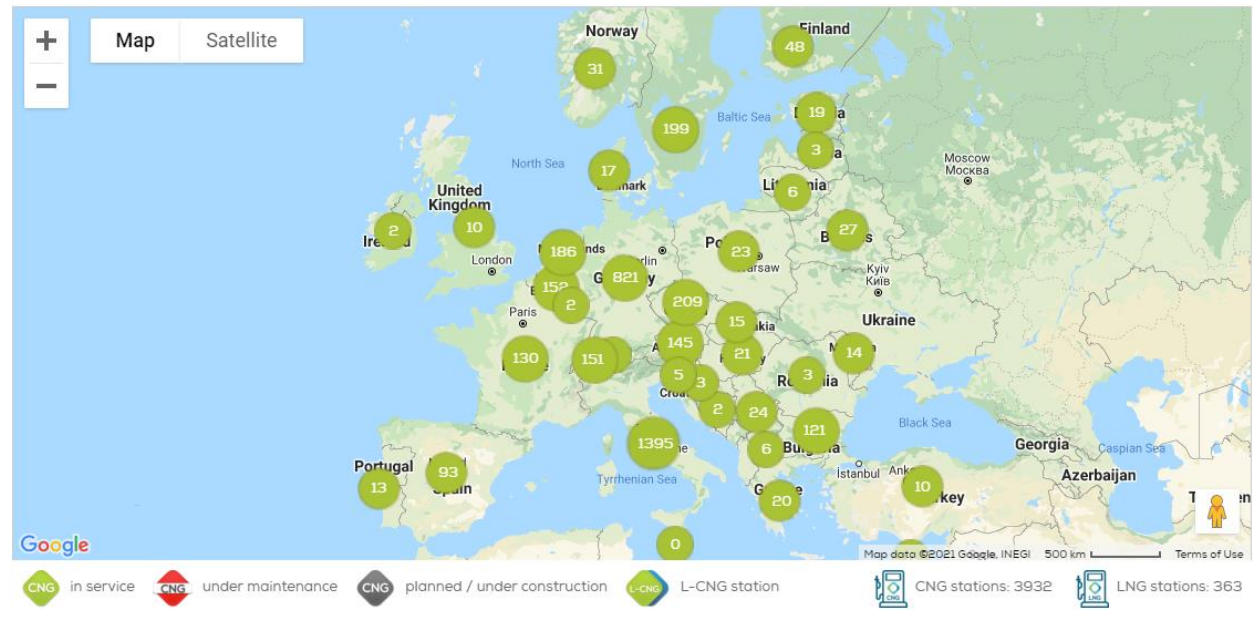

Figure 3. CNG refilling stations in Europe [31].

These being presented, methane gas has potential in terms of use for vehicles adapting them to the needs of sustainable mobility in the current context but also in the short to medium term.

\subsection{Influence of NG on SI Engine Operation}

\subsubsection{Combustion Characteristics}

For a better understanding of what happens inside the cylinder when running in CNG mode, in [33] a comparison between a turbocharged direct injection (DI) gasoline engine and same engine port fuel injected CNG was made and they faced the major problem that every manufacturer and investigator is facing: the torque loss in CNG operating mode [3], [33]. Due to stoichiometric (air-fuel) AF ratio of CNG(17.2) [33] higher than the one for gasoline (14.5) [33], discussing at iso-air filling, the amount of natural gas injected or which goes inside cylinder is smaller than the gasoline one. Furthermore in this experiment, the CNG was injected in a gaseous state into the intake port and that meant an unfavourable volumetric efficiency which cumulated with the stochiometric $\mathrm{AF}$ ratio of $\mathrm{CNG}$, means that the total energy of CNG was lower than gasoline, which is one of the possible reason for the torque loss [33].

Another possible reason for torque loss is the low flame propagation, [18], [3], [34] which is lower than gasoline. This means that for the same spark advance applied the duration of combustion will be higher for CNG. In [33] an earlier spark advanced ignition timing was applied and the duration of combustion was nearly identical after top dead centre (TDC). Also, in [3] the same recommendation is made in order 
to have the same duration of combustion. Another consequence of low flame propagation is the longer ignition delay compared with a diesel or a gasoline engine. Consequently, the duration of combustion becomes longer. Bi-fuel engines are optimised with more advance spark timing in gasoline cases and a pilot injection for the diesel engines which ignites the CNG [3]. Ignition delay can be also improved by changing the combustion chamber geometry [3] or using a direct injection of CNG which proves similar performances as a DI gasoline engine [35].

These two parameters, low flame propagation and ignition delay, entail temperature and cylinder pressure modification. In [36], for the same spark advance applied the pressure inside cylinder is significantly smaller especially near TDC because the gas occupy volume in the admission collector and the air which goes inside is less and because the burning velocity of the methane is smaller. Also, the temperature flame of the methane and air mixture is lower than gasoline mixture, so the ignition delay is longer which makes a reduction in cylinder pressure and in temperature as well. The increasing of the spark advance for natural gas operation and together with the elimination of the cooling effect of the fuel vaporisation leads to higher temperatures inside the cylinder which explains the higher values of NOx [18],[33], which many investigators faced with. Cylinder pressure is also higher due to spark advance modification in order to obtain maximum brake thermal efficiency without going over maximum cylinder pressure of the engine [19], [33] (mechanical limitation).

\subsubsection{Engine Performance}

The external effects of the in-cylinder effects are quantified with the dyno. Break mean effective pressure is lower than gasoline operation with around 16\% [16]. The reason was already explained in \$2.4.1. as being an effect of the low flame propagation cumulated with ignition delay. That means that the torque decreases between $14 \%$ [18] and $15 \%$ to $20 \%$ for retrofitted engines [3] confirmed also in [16]. Power decreasing is a consequence of the torque decreasing.

Higher octane number of CNG in concordance with the spark advance applied has consequences about exhaust gas temperatures, too. In [33], excepting the low speed part where the manifold pressure was different, the exhaust temperature was reduced so much that no enrichment was needed. Also, in [3] a decrease of $6.8 \%$ of the exhaust temperature was observed.

Brake specific fuel consumption was always lower in CNG operating mode which can be explained by three main factors: higher heating value of CNG than gasoline, lean and slow burning of CNG and earlier spark advance applied in CNG mode which also improves brake thermal efficiency (BTE) up to $5-12 \%$ [33], [3]. The lower value of BSFC is in range $12 \%$ to $20 \%$ lower than gasoline [16], [18], [33], [3]. In [37] is presented the influence of compress ratio for a diesel dual fuelled engine on BSFC, which also help in decreasing it. This is the main advantage of a spark ignited engine which operates with CNG.

\subsubsection{Emissions}

In [36], a naturally aspirated gasoline engine port fuel injected was compared with itself but with CNG fuel. The spark advance was not modified. In this case the torque was lower with $19 \%$ than the gasoline operating mode. The authors presented all the pollutants as being lower than the operation with gasoline and mentioned that $\mathrm{CO}_{2}$ is reduced up to $90 \%$ and the $\mathrm{UHC}$ is reduced up to $12 \%$ to $96 \%$, as function of load. The NOx depends on the combustion temperature and it is reduced around $68 \%$ in full load and up to $90 \%$ in partial loads.

About carbon monoxide (CO) emissions, in [38], $37 \mathrm{CNG}$ vans were tested in two different laboratories and in contrast with their gasoline counterparts, they produced $40 \%$ lower $\mathrm{CO}$ emissions. According to [38], [39], CNG particles size are smaller than diesel $(0.1 \mu \mathrm{m})$ and gasoline $(0.01-0.08 \mu \mathrm{m})$ with ranges 
between 0.01 to $0.07 \mu \mathrm{m}$ with a majority between 0.02 and $0.06 \mu \mathrm{m}$. Same study shows that the average total particulate mass (PM) of CNG engine is only between 7 to $9 \%$ of the emissions of a diesel engine [38], [40].

About particulate number (PN), an Euro6 CNG car in real driving emissions test, the number of particles greater than $23 \mathrm{~nm}$ were as low as a diesel particulate filter equipped engine. Measurements on the Euro 6 D-temp CNG vehicle shows that $\mathrm{PN}>2.5 \mathrm{~nm}$ levels are below the current regulation limits even without particulate filter on the exhaust line [41], [42].

Further to this literature review, it is clear that the natural gas will reduce the exhaust emissions for spark ignited engine, as already did in Delhi [43] where the air quality was improved with the help of CNG.

\section{Conclusions}

After all arguments presented, natural gas vehicles should be part of the future of the internal combustion engine. Natural gas is available in many world locations; however, the necessary infrastructure should develop quicker than planned in order to ensure a more rapid use of this complementary clean fuel. Thanks to fast filling process, a natural gas vehicle has a main advantage in front of an electric vehicle car: filling time, which is comparable with a filling time of a gasoline or diesel car. The artificial production of bio-methane is also a high step because it can be produced from waste (water and food). It can easily be adapted to actual engine technology by adding some specific sensors and actuators. Direct injection CNG seem to be a solution in obtaining performances similar with a DI gasoline engine. Emissions are reduced with a high percentage especially in part loads where many vehicles operate day by day. CNG improves BSFC and BTE which has a direct impact in $\mathrm{CO}_{2}$ reduction. The results made on the retrofitted engines with $\mathrm{CNG}$ are promising regardless of the combination of CNG with other fuels or using pure CNG, and probably will have their best if a dedicated CNG engine will be created (combustion chamber, compression ratio) and fully optimised (spark advance, fuel injected mass).

\section{Abbreviations}

$\begin{array}{llll}\text { AF } & \text { air fuel } & \text { LNG } & \text { liquefied natural gas } \\ \text { BEV } & \text { Battery electric vehicle } & \text { LPG } & \text { liquefied petroleum gas } \\ \text { BP } & \text { brake power } & \text { NG } & \text { natural gas } \\ \text { BSFC } & \text { brake specific fuel consumption } & \text { NGV } & \text { natural gas vehicle } \\ \text { BTE } & \text { brake thermal efficiency } & \text { NGVA } & \text { Natural \& bio-Gas vehicle association } \\ \text { CNG } & \text { compressed natural gas } & \text { PC } & \text { passenger car } \\ \text { CO } & \text { Carbon monoxide } & \text { pcyl } & \text { cylinder pressure } \\ \text { CR } & \text { compress ratio } & \text { PHEV } & \text { plug-in hybrid electric vehicle } \\ \text { DI } & \text { direct injection } & \text { PM } & \text { Particulate matter mass } \\ \text { DoC } & \text { duration of combustion } & \text { PN } & \text { Particulate number } \\ \text { ECU } & \text { electronic control unit } & \text { SI } & \text { spark ignition } \\ \text { EGT } & \text { exhaust gas temperature } & \text { Tcyl } & \text { cylinder temperature } \\ \text { GHG } & \text { green house gases } & \text { TDC } & \text { top dead centre } \\ \text { ID } & \text { ignition delay } & \text { UHC } & \text { unburned hydrocarbons } \\ \text { IMEP } & \text { indicated mean effective pressure } & \text { ULEV } & \text { ultra-low emission vehicle } \\ \text { LHV } & \text { lower heating value } & \text { ZEV } & \text { zero emission vehicle }\end{array}$

\section{References}

[1] European Parliament and Council of the European Union, "Regulation (EC) no. 443/2009," 
Off. J. Eur. Union, vol. 140, no. 1, pp. 1-15, 2009, [Online]. Available: http://eurlex.europa.eu/LexUriServ/LexUriServ.do?uri=OJ:L:2009:140:0001:0015:EN:PDF.

[2] ICCT, "EU CO2 EMISSION STANDARDS FOR PASSENGER CARS AND LIGHTCOMMERCIAL VEHICLES," 2014.

[3] M. I. Khan, T. Yasmin, and A. Shakoor, "Technical overview of compressed natural gas (CNG) as a transportation fuel," Renew. Sustain. Energy Rev., vol. 51, no. December 2017, pp. 785-797, 2015, doi: 10.1016/j.rser.2015.06.053.

[4] EU, DIRECTIVE 2014/94/EU OF THE EUROPEAN PARLIAMENT AND OF THE COUNCIL on the deployment of alternative fuels infrastructure. Official Journal of the European Union, 2014.

[5] M. Westerhoff, "Natural gas. A chance to be grabbed," MTZ, vol. 76, no. February, pp. 9-13, 2016.

[6] G. T. Chala, A. R. A. Aziz, and F. Y. Hagos, "Natural Gas Engine Technologies: Challenges and Energy Sustainability Issue," Energies, vol. 11, no. 11, 2018, doi: 10.3390/en11112934.

[7] R. Tilagone, S. Venturi, and G. Monnier, "Natural gas - An environmentally friendly fuel for urban vehicles: The smart demonstrator approach," Oil Gas Sci. Technol., vol. 61, no. 1, pp. 155-164, 2006, doi: 10.2516/ogst:2006010x.

[8] ***, "Country comparison: natural gas production," The CIA world factbook. https://www.cia.gov/the-world-factbook/field/natural-gas-production/country-comparison (accessed Jan. 31, 2021).

[9] "Natural gas extraction." http://naturalgas.org/naturalgas/processing-ng/ (accessed Jan. 30, 2021).

[10] “Natural Gas.” https://en.wikipedia.org/wiki/Natural_gas\#Natural_gas (accessed Jan. 30, 2021).

[11] Krzysztof Ziemiński, "Methane fermentation process as anaerobic digestion of biomass: Transformations, stages and microorganisms," African J. Biotechnol., vol. 11, no. 18, pp. 4127-4139, 2012, doi: 10.5897/ajbx11.054.

[12] P. Weiland, "Biogas production: Current state and perspectives," Appl. Microbiol. Biotechnol., vol. 85, no. 4, pp. 849-860, 2010, doi: 10.1007/s00253-009-2246-7.

[13] M. Frac and K. Ziemiński, "Methane fermentation process for utilization of organic waste," Int. Agrophysics, vol. 26, no. 3, pp. 317-330, 2012, doi: 10.2478/v10247-012-0045-3.

[14] ت. : "رسولى "Performance and emissions characteristics investigation of a bi-fuel SI engine fuelled by CNG and gasoline."

[15] G. Genchi and E. Pipitone, "Octane Rating of Natural Gas-Gasoline Mixtures on CFR Engine," SAE Int. J. Fuels Lubr., vol. 7, no. 3, pp. 1041-1049, 2014, doi: 10.4271/2014-01-9081.

[16] M. U. Aslam, H. H. Masjuki, M. A. Kalam, H. Abdesselam, T. M. I. Mahlia, and M. A. Amalina, "An experimental investigation of $\mathrm{CNG}$ as an alternative fuel for a retrofitted gasoline vehicle," Fuel, vol. 85, no. 5-6, pp. 717-724, 2006, doi: 10.1016/j.fuel.2005.09.004.

[17] J. S. Wallace, "A comparison of compressed hydrogen and CNG storage," Int. J. Hydrogen Energy, vol. 9, no. 7, pp. 609-611, 1984, doi: 10.1016/0360-3199(84)90241-6.

[18] A. H. Shamekhi, N. Khatibzadeh, and A. Shamekhi, "A comprehensive comparative investigation of compressed natural gas as an alternative fuel in a bi-fuel spark ignition engine," Iran. J. Chem. Chem. Eng., vol. 27, no. 1, pp. 73-83, 2008.

[19] M. M. Tahir et al., "Performance analysis of a spark ignition engine using compressed natural gas (CNG) as fuel," Energy Procedia, vol. 68, pp. 355-362, 2015, doi: 10.1016/j.egypro.2015.03.266.

[20] B. Y. Ti, "Chemical properties Chemical properties of ELLASTOLAN," vol. 2, pp. 36-46, 2020.

[21] R. H. Crabtree, “Aspects of Methane Chemistry,” Chem. Rev., vol. 95, no. 4, pp. 987-1007, 1995, doi: 10.1021/cr00036a005.

[22] "Methane," 2015. http://www.ilo.org/dyn/icsc/showcard.display?p_version=2\&p_card_id=0291 (accessed Jan. 30, 2021).

[23] C. Soruşbay, "Otto cycle,” Wikipedia, pp. 1-14, 2015, [Online]. Available: 
https://en.wikipedia.org/wiki/Otto_cycle.

[24] "Energy density." https://en.wikipedia.org/wiki/Energy_density (accessed Jun. 07, 2020).

[25] P. Examiner, W. D. Griffin, E. Kenneth, and J. H. Harwell, "United States Patent (19)," no. 19, 1999.

[26] “CNG vs LPG." https://www.elgas.com.au/blog/1698-cng-vs-lpg-comparing-propertiessources-uses-homes-cars-vehicles\%0A (accessed Feb. 02, 2021).

[27] R. B. Gmbh, N. Gas, E. Management, and G. Injector, "Natural Gas As an Alternative Fuel for Motor," no. 1.

[28] "How do bifuel natural gas cars works." https://afdc.energy.gov/vehicles/how-do-bifuelnatural-gas-cars-work (accessed Jan. 30, 2021).

[29] R. A. B. Semin, "A Technical Review of Compressed Natural Gas as an Alternative Fuel for Internal Combustion Engines Semin , Rosli Abu Bakar Automotive Excellent Center, Faculty of Mechanical Engineering," Am. J. Eng. Appl. Sci., vol. 1, no. 4, pp. 302-311, 2008.

[30] M. Trudgeon, "An Overview of Ngv Cylinder Safety Standards, Production and in-Service Requirements .," Assoc. Port. do Veículo a Gás Nat., no. July, pp. 1-11, 2005.

[31] "NVGA Europe map." https://www.ngva.eu/stations-map/ (accessed Jan. 30, 2021).

[32] "LPG stations." https://www.eafo.eu/alternative-fuels/lpg/filling-stations-stats (accessed Feb. 02, 2021).

[33] J. Lee, C. Park, J. Bae, Y. Kim, S. Lee, and C. Kim, "Comparison between gasoline direct injection and compressed natural gas port fuel injection under maximum load condition," Energy, vol. 197, p. 117173, 2020, doi: 10.1016/j.energy.2020.117173.

[34] M. Baloo, B. M. Dariani, M. Akhlaghi, and I. Chitsaz, "Effect of iso-octane/methane blend on laminar burning velocity and flame instability," Fuel, vol. 144, pp. 264-273, 2015, doi: 10.1016/j.fuel.2014.11.043.

[35] H. L. Husted, D. G. Karl, D. S. Schilling, and C. Weber, "Direct Injection of CNG for Driving Performance with Low CO2," 23rd Aachen Colloq. Automob. Engine Technol. 2014, no. 2, pp. 829-850, 2014.

[36] K. Nguyen Duc, V. Nguyen Duy, L. Hoang-Dinh, T. Nguyen Viet, and T. Le-Anh, "Performance and emission characteristics of a port fuel injected, spark ignition engine fueled by compressed natural gas," Sustainable Energy Technologies and Assessments, 2019. https://doi.org/10.1016/j.seta.2018.12.018.

[37] B. Road, "Performance and Exhaust Gas Emissions Analysis of Direct Injection Cng-Diesel Dual Fuel Engine," Int. J. Eng. Sci. Technol., vol. 4, no. 3, pp. 833-846, 2012.

[38] M. I. Khan, T. Yasmin, and A. Shakoor, "International experience with compressed natural gas (CNG) as environmental friendly fuel," Energy Syst., vol. 6, no. 4, pp. 507-531, 2015, doi: 10.1007/s12667-015-0152-x.

[39] A. P. Singh, A. Pal, and A. K. Agarwal, "Comparative particulate characteristics of hydrogen, CNG, HCNG, gasoline and diesel fueled engines," Fuel, vol. 185, pp. 491-499, 2016, doi: 10.1016/j.fuel.2016.08.018.

[40] K. Lehtoranta et al., "Controlling emissions of natural gas engines," Proc. Air Waste Manag. Assoc. Annu. Conf. Exhib. AWMA, 2017.

[41] B. Giechaskiel, U. Manfredi, and G. Martini, "Engine Exhaust Solid Sub-23 nm Particles: I. Literature Survey," SAE Int. J. Fuels Lubr., vol. 7, no. 3, pp. 950-964, 2014, doi: https://doi.org/10.4271/2014-01-2834.

[42] A. Mamakos, U. Manfredi, G. Martini, A. Perujo, and A. Marotta, Physical Characterization of Exhaust Particle Emissions from Late Technology Gasoline Vehicles. 2012.

[43] A. B. Chelani and S. Devotta, "Air quality assessment in Delhi: Before and after CNG as fuel," Environ. Monit. Assess., vol. 125, no. 1-3, pp. 257-263, 2007, doi: 10.1007/s10661-006-9517$\mathrm{x}$. 